\title{
'An Almost Unheard-of Analogy': Derrida Reading Levinas
}

\author{
Kas Saghafi
}

This word "other" is very soon, I predict, going to become absolutely unutterable, given the abuse or the inflation to which it has fallen victim.

\section{-Jacques Derrida}

Show yourself! Reveal yourself to me so that I can see you!

This is the demand-the appeal-that Moses addresses to God. In the well-known passage from the Book of Exodus, Moses is said to implore God: "I beseech thee, show me thy glory" (Exodus 33:18 AV). However, his entreaty is swiftly denied when God replies: "Thou canst not see my face: for there shall no man see me, and live" (33:20). All that Moses can hope for is to see the "back parts" of God. "But my face," he is assured, "shall not be seen" (33: 23).

Hachem Foda, a Professor of Arabic literature, invokes this very relationship between Moses and God in a meeting of several Arab intellectuals with Jacques Derrida in Rabat, Morocco, that took place in June 1996. In a paper analyzing a series of Arabic terms having to do with the notion of uns (a concept that encompasses sociality and warm companionship with others as well as with God), Foda claims that any communion or relation with God is only possible in terms of a friendly and intimate relation that one shares with one's neighbors. Foda refers to Kalâbâdhîs Treatise on Sufism, whose author quotes the words of the Egyptian mystic Dhu 1-Nun. ${ }^{1}$ Uns or intimacy with God, 


\section{KAS SAGHAFI}

the mystic is to have said, "is for the one who loves, being at ease with the beloved [être à l'aise avec l'Aimé]" (IND 20). As an example of the desire for uns, for this intimacy and comfort, Kalâbâdhî cites the demand that Moses is said to have placed on God: "Show yourself to me, so that I can see you."' It is the very desire for uns, according to Foda, that motivates Moses to want to see God. And the response from God"you will never see me"-Foda believes, demonstrates that divinity as such does not belong to the phenomenal order. ${ }^{3}$ Thus, having God as companion, Foda writes, is akin to "having company without companions," it is "being with no one [être avec personne]," or "being in the company of no one [être en compagnie de personne]" (IND 30).

In his response to Foda's paper, Jacques Derrida not only highlights the almost Blanchotian reference to companionship with this some one "who does not accompany me" but also the example of the relation between Moses and God. What Foda's paper reveals, Derrida wants to suggest, is precisely the impossibility of being able to rigorously distinguish between the relation to the other and the relation to God. The scene in which Moses asks God to show himself and God refuses visibility, Derrida provocatively claims, can in fact be taken as "the paradigm for all relations to the other [l'autre], whatever it may be [quel qu'il soił], human or divine."4 If, the other's manner of presenting itself - in a relation of interruption and separation, dissociation and disjunction - consists in not ever presenting itself, then, the relation to alterity in general, this experience of an invisibility in the visible or of a non-phenomenality, is a relation where the other "can only present itself as other, never presenting itself as such" (IND 226). The condition of the experience of the other as other is that we can never have direct access to the other side, "to the zero point of this other origin of the world," in the same manner that there can be no immediate intuition or originary perception of the alter ego. "Isn't this," Derrida asks, "the law of the relation to the other, whatever it may be [quel qu'il soit, $\mathrm{X}$, animal, God or human being?"(IND 226). In other words, the law of the relation to the other entails that all relations to the other, each relation to every other - and tout autre est tout autro-is an interruptive rapport to the distant, the inaccessible, and the secret.

Contrasting his belief in the impossibility of clearly distinguishing between the relation to the other and the relation to God with Levinas's thought, which wishes to maintain a distinction, however tenuous, between the two relationships, Derrida asks: "When Levinas speaks of the Wholly Other [Tout Autre], or of the infinitely Other, does he 


\section{'AN ALMOST UNHEARD-OF ANALOGY'}

speak of God or the other in general?" (IND 220). ${ }^{5}$ In other words, can Levinas's Tout Autre be rigorously distinguished from any other "other?" Doesn't Levinas "set up [s'installe] an analogy between the relation of Moses to God and the relation of man to man, that is of every other to every other, of every other to the wholly other, to every other of the wholly other, to the utterly other of the wholly other [de tout autre à tout autre, au tout autre de tout autre]"? (IND 226, my emphasis).

If there is such an analogy between the relation of Moses to God and the relation to the other, this gives rise to a number of questions: How are we to read this analogy? How are the terms of the analogical relation (God, for example) and the analogical relation itself read in Derrida's work, so that the relation of Moses to God can be designated as "the paradigmatic" relation? Further, how is the function of the paradigm re-worked in Derrida's texts? Finally, and most importantly, who or what is "the other [l'autre]" for Derrida?

In what follows, I would like to suggest, that from very early on (certainly as early as 1964, perhaps even earlier), what has been at work in Derrida's writings is a sophisticated notion of the other [l'autre] that needs to be distinguished from that of his contemporaries. Always written in the lower case, the other, for Derrida, can designate the alterity of Autrui, as well as encompassing what has traditionally been understood as a formal or logical sense of alterity (for example, in the Hegelian and Husserlian sense) without being reduced to it. Echoing the concerns of "Violence and Metaphysics," Derrida's l'autre, combines the features of the absolutely other and the alter ego, thus yoking the Hebraic and Hellenic, while keeping each heterogeneous.

\section{The Last Word: "Violence and Metaphysics"}

Derrida's discussion of the relation between Moses and God in Morocco recalls, of course, an earlier passage in his first, and now seminal, evaluation of Levinas's work, "Violence and Metaphysics: An Essay on the Thought of Emmanuel Levinas," where he had quoted the section from Exodus with which my essay began. ${ }^{6}$ In "Violence and Metaphysics" Derrida had taken Levinas to task, arguing that the descriptions of the relation to Autrui detailed in Totality and Infinity evoked "the Lord speaking face to face with Moses" (ED 160/108). The resemblance of the Face of Yahweh-never explicitly mentioned in Totality and Infinity-to that of Autrui was, for Derrida, the sign of an "equivocal complicity between theology and metaphysics in Totality 


\section{KAS SAGHAFI}

and Infinity" (ED 160/108-9). Levinas's ethics, then, was inevitably contaminated by an inescapable theological conceptuality, making it susceptible to a critique of onto-theology. Yet, many years later, Derrida cites this very relationship of Moses to God as the paradigm for all relations to the other. How are we to assess Derrida's seemingly contradictory account in Morocco in light of his earlier condemnation? Is it the case, as many suspect or fear, or as they always suspected, that Derrida has become unseemly religious? Or is Derrida's re-reading of the analogy between the relation of Moses to God and that of the relation to the other, part of an enriched approach to Levinas's corpus, a re-appreciation of Levinas, mainly marked in Derrida's work not specifically devoted to Levinas - a reconsideration fully aware of the aporias of giving and generosity, gratefulness and ingratitude-that has been taking place for more than two decades? Is it perhaps a case of the reinscription of certain initially censured terms-terms such as the absolutely other, experience, religion, and so on -allowing the terms and the relation to Levinas to be read anew?

In "Violence and Metaphysics," a long, wide-ranging, detailed, and dense essay which for many in France and elsewhere served as the first introduction to Levinas's work and has to a certain extent determined the reception of Levinas's work, Derrida presented Levinas's challenge to Husserlian phenomenology and Heideggerian ontology as a fundamental thinking of the other [l'autre]. In a multitiered, complex examination of Levinas's reading of Husserl and Heidegger, Derrida employed the double gesture of (1) using the resources of the very thinker criticized by Levinas to pose questions to Levinas's own interpretations, and (2) in a further twist, using a Husserlian orientation to question Levinas's interpretation of Heidegger and a Heideggerian path to criticize Levinas's take on Husserl. Since its republication in Writing and Difference in 1967, this complicated essay has acquired the status of a canonical text, conveniently becoming the obligatory reference and final arbiter whenever the question of the relation between Derrida and Levinas is raised, even though the issues at stake in it are far from clear.

Even if, since then, Derrida has devoted a number of other texts to Levinas-in particular, "At This Very Moment in This Work Here I am" (1980) and Adieu (1996) -and the explicit references to Levinas's texts have grown exponentially over the years (for example, in The Gift of Death, Politics of Friendship, Le toucher, Jean-Luc Nancy, and "L'animal que donc je suis")—many still seem to consider "Violence and 


\section{'AN ALMOST UNHEARD-OF ANALOGY'}

Metaphysics" as the last word whenever the relation between the two thinkers is broached, in particular whenever any discussion of "the other" is concerned. The other-this term, notion or concept, which has been worn away by so much misuse, contributing to its banality, which has become a mantra in so many quarters, serving as shorthand for liberal concern for diversity and multiculturalism-has become a liability. There is too much talk of the other, we are told. And yet, we cannot do away with the other, since the other and the relation to the other are at the heart of the celebrated chiasm that joins and separates the oeuvres of Levinas and Derrida.

Part of the difficulty of appealing to "Violence and Metaphysics" to resolve all differences and to explain the relation between two thinkers, however, is that practically all of the complaints or objections addressed to Levinas have since been affirmatively reinscribed and reworked in Derrida's own work. Thus, instead of treating "Violence and Metaphysics" as if it were the last word, as if everything that Derrida has written on Levinas and the other since 1964 ought to be judged against the formulations of that text, much care needs to be taken to avoid conflating the work of the two thinkers and to disentangle the thought of the other in Derrida from its Levinasian legacy. A more careful, deliberate, and patient exercise, for example, would consist of attending to the usage of the term l'autre in all of Derrida's texts, in order to gain a better sense of how it functions in his work-an enormous task indeed. Yet, even if we turn to "Violence and Metaphysics" in a very circumscribed manner and attentively read a few selected passages where Derrida poses a number of questions to Levinas, to his reading of Husserl (and the alter ego) and to Levinas's own notion of Autrui, we may be able to catch a glimpse of the moments in Derrida's text where it has already begun to pull away from Levinas, displacing the privilege of $A$ utrui and articulating another thinking of the other [l'autre]. In order to do so, it is necessary to draw out Derrida's remarks regarding the other in "Violence and Metaphysics," beginning with Husserl's notion of the alter ego and then Levinas's notion of Autrui.

\section{Reading Husserl}

Undertaking a rigorous re-appraisal of Husserl's work, Derrida attempts to show in "Violence and Metaphysics" that, despite Levinas's criticisms, Husserl's concern has always been with the other as other. It 
is worth noting that the "objections" addressed to Levinas-who after all co-translated the Cartesian Meditations_-audacious though they may be, revolve around Levinas's interpretations of Husserl. Derrida's comments particularly address the adequacy of Husserl's account of the relation to the other. By broaching the topics of the alter ego and the irreducibly mediate relationship with the other (analogical appresentation), Derrida demonstrates Husserl's attentiveness to respect and preserve the alterity of the other. Husserl's descriptions of the alter ego, Derrida claims, recognize the other as other, in its form as ego and in its form of alterity.

Derrida notes that a schema undergirds all of Levinas's thought of the other: the other [l'autre] is other [l'autre] only if its alterity is absolutely irreducible, that is, infinitely irreducible (ED 154/104). In other words, the other is absolutely other, it is "exteriority which can be neither derived, nor engendered, nor constituted on the basis of anything other than itself" (ED 156/106). According to Levinas, Husserl's determination of the other as alter ego in the Fifth Cartesian Meditation implies that the other is the same as the ego. Derrida presents Levinas's argument thus: "By making the other [l'autre] a phenomenon of the ego, in particular in the Cartesian Meditations, constituted by analogical appresentation on the basis of the ego's own sphere of belonging, Husserl missed the infinite alterity of the other [l'autre], reducing it to the same" (ED 180/123). To make the other [l'autre] an alter ego would be, for Levinas, tantamount to a neutralization of its absolute alterity.

Let us now follow very closely Derrida's argumentation in "Violence and Metaphysics" in order to examine how he sets out to contest Levinas's interpretation and to demonstrate that Husserl's work is in fact rigorously faithful to the alterity of the other. ${ }^{9}$ Derrida raises a number of points, the most important of which are: (1) the status and (2) appearing of the alter ego, (3) the mediate relationship to the other or analogical appresentation, (4) the alterity of bodies, and (5) the economic relationship between symmetry and asymmetry.

(1) The Alter Ego as Ego. The criticism that Levinas has leveled at Husserl is that he maintains that the other ['autre] as alter ego is known through sympathy_"as another like myself" (ED 184/125). As we know, for Levinas, Autrui is not simply an alter ego. But for Husserl, as Derrida points out, the other [l'autre] is never me but "an Ego [un Mol]," it has the form of the ego (ED 162/110, italics in original). Thus Husserl understands the other as alter ego to mean "the other as 
other [l'autre comme autre]" (ED 184/125, my italics). Precisely because it is an ego, it is "irreducible to my ego" (ED 184/125). It is "the egoity of the other [l'autre]," Derrida adds, that allows him to say "ego," and "this is why he is autrui and not a stone, or a being without speech in my real economy" (ED 184/125). Husserl recognizes the Other [autru] "in its form of alterity [dans sa forme d'alterite]," which cannot be that of things in the world (ED 184/125). Without the recognition of the other as a transcendental alter ego, Derrida notes, "its entire alterity would collapse" (ED 184/125). Thus, for Husserl, the "passage from Ego [Mol] to the other [l'Autre] as an Ego is the passage to the essential, non-empirical egoity of subjective existence in general" and not a passage to that of my ego (ED 162-3 /110).

(2) The Alter Ego Appears to Me. In the Cartesian Meditations, Husserl is concerned to show "how the other as other [l'autre en tant qu'autr], in its irreducible alterity, presents itself to me," appears to me (ED 180$1 / 123$, my italics). There has to be, Derrida insists, "a certain appearing of the other as other to an ego" (ED 181/123, my italics). It would be impossible to encounter the alter ego and respect it in experience and language "without this other, in its alterity, appearing for an ego (in general)" (ED 181/123). There has to be a phenomenon of the totally other, "otherwise one could neither speak, nor have any sense of the totally other [tout-autre], or evidence of the totally other as such" (ED $181 / 123)$. But the other as other is "the phenomenon of a certain non-phenomenality," its mode of appearing is that of "an originary non-presence" (ED 181/123). Thus Husserl's writings, Derrida states, can be said to "describe the system of the phenomenality of nonphenomenality" (ED 183/125). The other [l'autre], "phenomenality as disappearance [comme disparition]," 'appears' but never as such (ED 190/ 129). It is this appearing of the other [l'autre] as what I can never be, Derrida notes, this "originary non-phenomenality," that is examined as "the intentional phenomenon of the ego" (ED 182/123).

(3) The Mediate Relationship to the Other or Analogical Appresentation. Husserl's central concern in the relationship with the other is "the irreducibly mediate character of intentionality aiming at [visant] the other as other" (ED 182/123). Husserl is most insistent that "the other as transcendental other (the other absolute origin and the other zero point in the orientation of the world)" can never be given to me in person, but only through analogical appresentation (ED 182/124). ${ }^{10}$ The alter ego cannot present itself, it cannot become an originary presence for the ego, it can never be given "in person," thus resisting the principle 


\section{KAS SAGHAFI}

of principles of phenomenology-namely, the intuitive given of originary presence. ${ }^{11}$

Derrida notes that the relation of analogical appresentation is not an assimilating reduction of the other to the same, but rather "confirms and respects separation, the unsurpassable necessity of (nonobjective) mediation...If I attained the other immediately and originally, silently, in communion with the other's own experience, the other would cease to be the other" (ED 182/124). Contrary to appearances, appresentative transposition recognizes "the radical separation of absolute origins, the relation of absolved absolutes [absolus absous] and non-violent respect for the secret" (ED 182/124).

Throughout all of his writings, Derrida never abandons the importance accorded to analogical appresentation in his reading of Husserl. Over thirty years later in Le toucher, Jean-Luc Nancy, Derrida, while praising "Husserlian prudence" as "a model of vigilance," reiterates the necessity of turning to analogical appresentation. ${ }^{12}$ Noting the "unsurpassable abyss [abime infranchissable]" separating me from the other, Derrida emphasizes that the other [l'autre] is never given to me immediately, is never "presented" directly, but is "apprehended" in an indirect relationship. My access to the body (Leib) of the other, he writes in Le toucher, is only possible in "an indirect fashion, by appresentation, comparison, analogy, projection, and introjection" (LT 217). My relation to the other's body, in contrast to the relation the other has to its own body, can only be through appresentation. The other, "from its point of view [de son côte], which will never be mine, has an originary relation to its body," the same way I have to mine, which I will never have with its (LT 217). I can never have an experience of the other's body as if I were on its side. Thus "one must be vigilant about the alterity of the other [il faut veiller à l'altérité de l'autre]: the latter will always remain inaccessible to an originary giving [donatrice] intuition, an immediate and direct presentation of bere [icc]" (LT 218). Even though I may know or feel that "there is an other here [ic]]," this other 'here" presents itself as that which will never be mine. It is not possible to confuse me and the other because "the alterity of the alter ego can never be reappropriated in the ownness [le propre] of 'my ego"' (LT 220). Each of our worlds is untranslatable, Derrida writes, and at bottom there will never be the 'same world' [au fond il n'y aura jamais de «même mondes) (LT 220). There is an irreducible difference between us-I have a direct and originary intuition of my body and an indirect appresentation that gives me access to the other. The interiority of the 


\section{'AN ALMOST UNHEARD-OF ANALOGY'}

other cannot be given to me immediately, it cannot be $m y$ interior life. I have access to the other, but only as other and not as another me.

(4) Things and Alterity in General. In "Violence and Metaphysics," Derrida is also keen to point out that Husserl's attentiveness to alterity is not simply confined to that of the alter ego but also applies to the alterity of things: "Bodies, transcendent and natural things are others [des autres] in general for my consciousness. They are outside and their transcendence is the sign of an already irreducible alterity" (ED 182/ 124). Despite Levinas's protestations, wishing to reserve alterity for Autrui, Husserl maintains that alterity is also applicable "when things are concerned [quand il s'agit des choses]" (ED 182/124). This understanding of alterity, according to Derrida, "takes seriously the reality of the external world" (ED 182/124). What things share with autrui is a general alterity, as witnessed by the fact "that something in them is always hidden [se cache aussi toujours], and is indicated only by anticipation, analogy and appresentation" (ED 182/124).

The already irreducible alterity of the transcendent thing is due to "the indefinite incompleteness [inachèvement] of my original perceptions" (ED 183/124). Even though the transcendent thing appears through adumbrations [Abschattungen], in principle "the possibility of an originary and original presentation" of a hidden side is always open (ED 183/124). However, in the case of autrui this possibility is foreclosed. The alterity of the transcendent thing is thus "incomparable with the equally irreducible alterity of autrul" since the alterity of autrui "adds to the dimension of incompleteness... a more profound dimension of non-originariness"- the radical impossibility of being able to "go around [faire le tour] to see things from the other side," of being able to experience the lived experience of the other from the other's vantage point (ED 183/124).

(5) AnEconomic Relation - Symmetry and Dissymmetry. It is important to note that without the alterity of bodies [les corps] (and autrui is, after all, also a body), the alterity of autrui could never emerge (ED 183/ 124). Derrida underscores that these two alterities-the alterity of bodies and the alterity of autrui-one inscribed in the other, need to be thought together. This is why the alterity of autrui is doubly irreducible, "by a double power of indefiniteness" (ED 183/124). The other remains infinitely other because "the subjective face of his expetience [vécu] from his vantage point [de son côte], such as it is lived by him" is never available to me (ED 183/124). Unlike what belongs to my sphere of ownness, the experience that the other has of what is 


\section{KAS SAGHAFI}

proper to him will never be given to me originally (ED 183/124).

Yet there is a strange symmetry between me and the other: I am also the other's other and I know this. Without this "evidence," I could not "desire (or) respect the other in ethical dissymmetry" (ED 188/ 128). It is precisely because "in my ipseity I know myself to be other for the other [autre pour l'autre]" that the movement of transcendence toward the other could have any meaning (ED 185/126). No dissymmetry would be possible without the symmetrical recognition of the other as ego. Derrida calls this dissymmetry "an economy in a new sense" (ED 185/126).

This economy - which Derrida concedes may sound logically absurd-is "the transcendental symmetry of two empirical asymmetries" (ED 185/126). ${ }^{13}$ This economic relation also entails, Derrida reminds us referring to Parmenides of the Poem and Plato's Sophist, that the other [l'autre] is always said pros heteron. ${ }^{14}$ The other cannot be absolutely "absolved" of relation to an ego; it cannot be absolutely exterior to the same without ceasing to be other. In other words, the other, even though utterly other, according to Derrida, must have some relation to the same. This would mean that the same cannot be a totality closed in upon itself, "an identity playing with itself with only the appearance of alterity" (ED 186/126). Citing Heidegger's Identity and Difference, where the same presupposes mediation, relation, and difference, Derrida argues that "the "play of the Same" is only possible when alterity is already lodged in the Same (ED 186/126-7).

(At this juncture it is essential to open a parenthesis to address the expression "infinitely other" or "absolutely other [absolument autre]" which, Derrida is to have stated, cannot be said and thought at the same time. This has led certain commentators, who hold steadfast to this as an iron-clad rule, to claim that what distinguishes Derrida from Levinas is that for the former the other can never be said to be "absolutely other." However, this would make it difficult to explain away the use of "the absolute other [l'autre absolu]" in Donner la mort (DM 97/68) and in a recent essay "L'animal que donc je suis" (L'animal autobiographique, 261) or comments such as: every other is "absolutely other [absolument autre]" or "infinitely other [infiniment autre]" (DM 110/ 78). A solution to this apparent contradiction or paradox can be found in exploring the expression "Tout autre est tout autre" which Derrida has used in a number of texts. ${ }^{15}$ For Derrida, there is a relation to the other who remains absolutely other, singular and unique).

The transcendental symmetry of two empirical asymmetries, the 
alterity of things, the mediate relationship to the other or analogical appresentation, the egoity of the alter ego and the necessity of its appearing, make up the core of Derrida's interpretation of Husserl's writings on the other, which insist that Husserl's work, by providing a rigorous account of the relation to the other as other, has always been thoroughly attentive to the alterity of the other. Even though Derrida provides an account of Husserl's work that differs from Levinas (for example, Levinas would deny that Autrui is an ego), he is insistent that no matter the particular interpretation or use of terminology (e.g., alter ego) Husserl's work is most attentive to the alterity of the other. ${ }^{16}$ Following an examination of Husserl, Derrida then turns his attention to Levinas's notion of Autrui.

\section{Levinas's Autrui and Derrida's 1'autre ${ }^{17}$}

As noted above, throughout his own writings, particularly from Totality and Infinity onward, Levinas makes abundantly clear that the absolutely other is Autrui, that is, only Autrui can be absolutely other. ${ }^{18}$ This "schema," Derrida emphasizes, underpins all of Levinas's thought on alterity (ED 154/104). In "Violence and Metaphysics" Derrida attends to both components of this axiom, scrutinizing what Levinas means by the terms "absolutely other" and "Autrui." We shall now examine the latter.

According to Levinas ontology has always conceptualized and totalized, hence neutralized, the relation to the other [l'autre]. But this relation-neither mediate, nor immediate-cannot be totalized by a concept of relation (ED 134/90). It is not possible to conceptualize the encounter, since the encounter itself is made possible by the other [l'autre]. The infinitely other, resistant to all categories, cannot be bound by a concept or thought on the basis of a horizon, since the concept supposes an anticipation and a horizon. For Levinas, the encounter with the other has the form of separation, the trace of which is at the heart of all experience (ED 141-2/95).

The infinitely other is invisible; it shows itself or appears in a certain non-manifestation (ED 135/91). It is in the face that the other is "given over in person as other [livre en personne comme autre], that is, as that which does not reveal itself, as that which does not allow itself to be thematized" (ED 152/103). The face which "is not of 'the world,"' can only be reached as the inaccessible, the separate, the invisible, the intangible, and the secret (ED 153/103). 


\section{KAS SAGHAFI}

If "the existence of autrui" escapes conceptualization, then what can be said about autrut? (ED 154/104). Who or what is autrul? Despite appearances, as Derrida points out, there is no concept of autrui (ED 154/104). In French, Autrui is not an adjective, or a pronoun; it is a substantive (i.e., it functions syntactically as a noun but is not a noun or a species of a noun). It is not a proper noun or a common noun either, and unlike the Greek category of the other in general, i.e. heteron, it does not take the definite article and admits no plural. Quoting the entry from the Littre, which states: "Autrui, from alter-huic, this other [cet autre]....Autrui is less general than "les autres "," Derrida asks how are we then to understand what is meant by autrui? (ED 155/105).

I would now like to turn to a couple of passages from a long paragraph in "Violence and Metaphysics" where, urging us to reflect upon "Autrui in an artisan-like way," Derrida's text indicates a schema for a re-reading of Levinas, at least of the terms autrui and l'autre (ED 154/104). Taking note of Derrida's emphases-he uses the phrase "Il faudrait réfléchir » five times on two pages-I would like to show how Derrida subtly questions the prominence and priority of the alterity of Autrui in Levinas's work (ED 154-5).

After citing the etymology of Autrui, Derrida wonders whether its capitalization, does in fact reinforce its neutrality. "We would have to reflect upon this word 'Autrui' in an artisan-like way [Ilfaudrait reflechir de façon artisanale]... this word 'Autrui' circumscribed in silence by the capital letter which ever increases the neutrality of the other [1'autre]...even though it is the very disorder of conceptuality" (ED 154/104-5). Next, in a difficult passage, Derrida highlights the relation of Autrui to heteron, the Greek genre or category of alterity relative to a point or term:

We should have to examine patiently [Il faudrait refléchir patiemment] what emerges in language when the Greek thought of beteron seems to run out of breath [semble s'essoufler] when faced by the alter-buic, seems to become incapable [semble devenir impuissante] of mastering what it alone, however, is able to precomprehend by concealing it as alterity (other in general) [dissimulant comme altérite (autre en generab)], that which, in return, will reveal to it the irreducible center of its meaning (the other as autrui) [('autre comme autrui)]. (ED 155/105)

It is worth examining, Derrida notes, whether beteron does "run out of breath" and whether it does become incapable of mastering 
what it only is able to pre-comprehend, i.e. Autrui. Does heteron, Derrida seems to be asking, conceal Autrui as other in general? Is it not worth reflecting on whether, as Levinas claims, Autrui is the "irreducible center" of the Greek thought of beteron? Levinas's resistance to the thought of beteron is a protest against the relativization of Autrui. According to Levinas, Autrui always falls outside the general and comparative Greek category of other. If, as Levinas holds, beteron has always concealed and pre-comprehended Autrui as alterity, as other in general, then, Derrida adds: "We would have to examine [Il faudrait reflecbin] the complicity of this dissimulation and pre-comprehension which is not produced within a conceptual movement, because the French word autrui does not designate a category [espèce] of the genre autre." In other words, Derrida is questioning whether there has been a "complicity" to dissimulate autrui.

Perhaps careful attention needs to be paid to a thought of l'autre in general, which should not be mistaken for that of a genre: "We should have to examine [Il faudrait reflechir] this thought of l'autre in general (which is not a genre), Greek thought within which this nonspecific difference realizes (itself in) our history" (ED 155/105). But how can we understand a thought of l'autre in general which would not be a genre? Here, we arrive at the crux of Derrida's questionioning of Levinas. Derrida queries: 'Even earlier [Plus tott]: What does autre mean before the Greek determination of heteron and the Judeo-Christian determination of autrue?" $E D 155 / 105) \cdot{ }^{19}$ Derrida is aware that such a question would meet tremendous resistance from Levinas, who would "contest it profoundly" (ED 155/105). For, according to Levinas, only the interruption of autrui would allow access to the absolute and irreducible alterity of the other. Derrida goes on to add that "we should have to examine, therefore, this Huic of autrui [Il faudrait donc reflecbir àce Huic d'autrui] whose transcendence is not yet of a thou [tor]," nor perhaps that of a He [I] (ED 155/105). ${ }^{20}$ Should a thinking of l'autre be limited to a choice between the invisible transcendence of autrui, Il, or that of a Buberian thou, tor? Is there the possibility of another option?

Derrida's dense, suggestive passage urges us to reflect, in an artisan-like fashion no less, (1) upon the two Latin components of Autrui-(a) the Huic, the this, and (b) the alter, the other, of alter-buicbut, even more profoundly, (2) calls for a thinking of l'autre prior or anterior to both beteron and Autrit.

1. (a) The "Huic of Autrui:" We know from Levinas's work that the this of autrui refers to this other human [l'autre bomme], differentiating 
it from all other forms of alterity. Autrui is thus the privileged form of alterity - this (buic), and not that, other (alter). By calling attention to the absolute singularity of the this, doesn't Derrida intimate that the this, the Huic need not only refer to this other human, but also to others, to all that is alter?

(b) The alter of alter-buic. In contrast to Levinas, Derrida in his reading of Husserl emphasizes the other as alter ego. To have a relation to the other as alter ego means to have a rapport with the other as other, an otberirreducible to my ego, precisely because it is an ego (see above section on Analogical Appresentation). Levinas seems to have underestimated or played down the alterity of the alter in alter-huic.

2. Derrida's very schematic comments here point toward a thinking of the other ['autre], anterior to beteron and autrui (ED 155/105). As we know, Levinas refuses to assimilate Autrui to beteron, since the former cannot refer to a general alterity or an alterity relative to a term. But, as Derrida demonstrates, referring to the notion of heteron in Plato's Sophist, heteron must not simply be thought in opposition to autrui. Derrida poses this question to Levinas: 'But how to think or say 'autrui' without reference-we do not say reduction - to the alterity of heteron in general?" (ED 186-7/127). Can there be a thinking of alterity that utterly absolves itself from relationality?

Heteron no longer has "the restricted meaning which permits simply opposing it to that of autrui, as if it was confined to the region of real or logical objectivity" (ED 186/127). If, as Derrida remarks, heteron belongs "to a more profound and originary zone than that in which is deployed this philosophy of subjectivity still implicated in the notion of autrui," then autrui must be thought with heteron (ED 186/127). A thinking of the other, l'autre, would not then be simply a thinking of otherness in general, or alterity relative to a term, or this absolutely other, Autrui, understood as this other human being and not any other being. A thinking that thinks the singular this of autrui and the beteron together at the same time would be, for Derrida, a thought of l'autre-prior to its simple determination as this other human or a general alterity-the thinking and writing of which becomes further refined in Derrida's own work. ${ }^{21}$

\section{The Relation to the Other}

What does the account of the relation to the other in "Violence and Metaphysics" teach us? What conclusions can be drawn about the relation to the other? Would it be desirable even to provide a formal 
account of this relation? Would such an account be able to do justice to the singularity of the other or would it run the risk of hypostasizing the other, endangering its alterity and thematizing what it seeks to investigate? In this essay Derrida praises "the nature of Levinas's writing," his way of proceeding, "masterfully progressing by negations, and by negation against negation. Its proper toute [Sa voie propre]," he writes, "is not that of an 'either this...or that' [uou bien ...ou bienn)] but of a 'neither this...nor that' [uni ...non pluss]" (ED 134-5/90). Thus one of the finest features of Levinas's writing is that it does not attempt to define or grasp the other, but its insistent rhythm strives to respect the singularity of the other. For, as Levinas comments, the relation to the other is "prior to the negative or affirmative proposition; it first institutes language, where neither the no nor the yes is the first word" (TI 32/42). It is necessary then to attend to the singularity of the other each time, while at the same time, attempting like Levinas to provide as nuanced an account as possible.

There can never be a relation to the other as such, for the other never appears as such. One can only have a relationship to the other as other. To have a relation with the other as other is to have a relation with the distant, the secret, and the invisible, beyond propriety, restitution, and the present, "there where the as such of the other eludes [se dérobe] phenomenality."22 My relation to the other is a relation to that which cannot present itself as such, never appears as such but only appears in disappearing. My relation is a relation to that which is not present, since if the other were actually present as such I would be able to appropriate it in my field of experience and it would be a phenomenon for me.

However, the relation with tout autre as such is a relation. This rapport sans rapport is a paradoxical relationship: "A relation without relation to any other relation," a relation with that which because of its "alterity and transcendance makes the relation impossible." ${ }^{23}$ In order to enter into relation with the other, it is necessary that an interruption be possible and that the relation be "a relation of interruption." However, this interruption does not simply interrupt the relation with the other; rather it opens the relation to it. In fact, all social bonds and ties presuppose and are made possible by such an interruption. As well as a relation of interruption, there is simultaneously a certain mediation in the relation to the other. In this other experience of mediationnot to be confused with a relation of reconciliation and totalizationthe other is understood as other in a certain relation of 
incomprehension. It is necessary that, at a given moment, the other remain as other.

Thus the relation to the other is twofold: there is (1) a suspension of opposition between binary oppositions, a mediation without opposition. At this moment one is in economy: between all oppositions there is no distinction or opposition, there is a difference (e.g. between nature and culture, where culture is nature differed and deferred, etc.), and at the same time (2) precisely because it suspends the opposition, there is a radical heterogeneity, the mark of radical difference or aneconomy. The relation to the other then is constituted by the two logics of economy (mediation without opposition) and aneconomy (radical alterity), relation and interruption of relation, interruption and negotiation.

\section{Resemblance to God}

Let us now return to the analogy between the relation to the other and the relation of Moses to God with which we began. A reading of analogy, as we shall show, is already hinted at in "Violence and Metaphysics," but it is Derrida's subsequent work on analogy that will enable us to read the analogical relation as resemblance and difference, economy and aneconomy. "The question of analogy" is itself raised in a discussion of the relation of Levinas' work to Hegel's (ED147-8/ 100). It is worth noting that Derrida italicizes the term "analogy" there, thus signaling that it is not being used in a conventional manner. ${ }^{25}$ This practice is true of practically every reference to analogy in Derrida's work. Referring to Levinas's statement that "Thought is language and is thought in an element analogous to sound and not to light," Derrida asks: "What does analogy mean here, difference and resemblance, a relation between the sensible sound and the sound of thought as intelligible speech, between sensibility and signification, the senses and sense?"(ED 147-8/99). Levinas employs an unusual analogy relating thought to speech in terms of sound rather than vision and light, an analogy rarely used in philosophy (hence one of the reasons for Derrida's subsequent use of the phrase "an almost unheard-of analogy"). If, according to Levinas, thought is language and more akin to sound than to light, then thought is being equated with speech, a living speech. Further, if, as Levinas claims, thought hears the invisible (God), then all speech [discours] would be a conversation with God.

We know that in Totality and Infinity the ethical relation with $A$ utrui 


\section{'AN ALMOST UNHEARD-OF ANALOGY'}

is speech or discourse [discours] and that Autrui is encountered in speech (TI 51/43). Discours would be the relation to the other as interlocutor. In the relation to the other, Autrui's manner of presenting itself is called "expression," and the face expresses itself kath auto. This is why Derrida can point out that the relation to the face in Levinas is only understandable in light of a certain resemblance of man to God (ED 159/108-9). Quoting from one of the "Conclusions" of Totality and Infinity, Derrida notes that "Autrui resembles God" (ED 159/108). ${ }^{26} \mathrm{It}$ is this very resemblance-_"the resemblance between man and God, man's face [visage de l'bomme] and the Face of God [la Face de Dien]" (ED 159/108) - no matter how radically thought by Levinas, which Derrida ultimately objects to, as it is the source from which both humanism and theology derive their impetus. ${ }^{27}$

In Totality and Infinity, Levinas cautions us that "it would be false to qualify [the relation to the absolutely other] as theological" (TI 32/ 42). Even though "the dimension of the divine opens forth from the human face," our relation with the other is "an ethical behavior and not theology," not "a knowledge by analogy of the attributes of God" (TI 76/78). "There can be no 'knowledge' of God," he later adds, "separated from the relationship with men. Autrui is the very locus of metaphysical truth, and is indispensable for my relations with God" (TI 77/78). Thus, Levinas further elaborates, "Autrui is not the incarnation of God, but precisely by his face, in which he is disincarnate, is the manifestation of the height in which God is revealed. It is our relations with men...that give to theological concepts the unique signification they admit of" (TI 78-9/77). Despite all of Levinas's qualifications, what Derrida still finds troubling in Totality and Infinity is the complicitous relationship of theology and metaphysics (ED 160/ $108-9)^{28}$

Derrida notes: "The face-to-face is thus not originally determined by Levinas as the vis-à-vis of two equal and upright men. The latter supposes the face-to-face of the man with bent neck and eyes raised toward God on high" (ED 158/107). In this resemblance, "The Face of God" commands while hiding itself, disappears in showing itself. What Derrida detects in this passage, and other passages like it, are evocations of the Face of Yahweh. Derrida cites the passage from Exodus with which I began, in which speaking face to face with Moses, God says: "Thou canst not see my face [ma face]: for there shall be no man see me and live...thou shall see my back parts: but my face shall not be seen" (Exodus 33:20-23). ${ }^{29}$ Derrida concedes that "the face [le 


\section{KAS SAGHAFI}

visage] is neither the face [la face] of God nor the face [la figure] of man: it is their resemblance. A resemblance which, however, we must think before, or without, the assistance of the Same" (ED 161/109).$^{30}$ (As we shall see, Derrida's comments in Rabat will enable us to think this resemblance otherwise)

The resemblance between the face and God's visage also sets up an analogy between speech between men and discourse with God:

Via the passageway of this resemblance, man's speech can be lifted up [re-monter] toward God, an almost unheardof analogy [analogie presque inouie] which is the very movement of Levinas's discourse on discourse, on speech [discours de Levinas sur le discours]. Analogy as [comme] dialogue with God: 'Speech [Le Discours] is conversation with God....Conversation with God, and not in God as participation. Conversation with God, and not discourse on God and his attributes as theology. (ED 159/108)

This "almost unheard-of" analogy, Derrida writes, is also the movement of Levinas's own discourse. In other words, Levinas's discourse (on discourse, that is, speech with God) is itself a speech addressed to God, making the status of his text, of all his writings, analogous to a conversation or dialogue with God. The nudity of the face-speech and look-is analogous to divine speech, the speech that instantaneously presents the speaker. The relation to God, in language and conversation, is therefore pre-supposed in every face-toface, and speech with God, always in the background, serves as "guarantor" for all face-to-face relations. It is in this sense that Derrida can write, paraphrasing Levinas, that the dissymmetrical relation to the other "is, perhaps, the very presence of God" (ED 159/108). Yet this "presence" is a strange presence:

Presence as separation, presence-absence as resemblance, but resemblance which is not the 'ontological mark' of the worker imprinted on his product (Descartes) or on 'beings created in his image and resemblance' (Malebranche), a resemblance which can be understood neither in terms of communion or knowledge, nor in terms of participation and incarnation. (ED 159-60/108)

For Levinas, this resemblance, which is not a sign or an effect of God, places us "in the Trace of God" (ED 160/108). But it is precisely this "resemblance" of man to God, the determination of Autrui by its 
resemblance to God, which prevents the face from appearing in relation with other beings: "It is the analogy between the face and God's visage [le visage avec la face de Dien] that, in the most classical fashion, distinguishes man from animal....Man's substantiality, which permits him to be face, is thus founded in his resemblance to God who is thus the Face [Le $V$ isage] and absolute substantiality" (ED 210/142). Levinas's theological conceptuality—or at least his rhetoric-reinforces the identification of the absolutely other as Autrui, my fellow human, and not as this other, whether animal, living, non-living, etc. Derrida remarks that Levinas's use of the language of "substance" ("perhaps man alone is substance"), refers us to the scholastic problematic of analogy, but he prefers to leave this issue aside (ED 210/143). ${ }^{31}$

\section{Rethinking Analogy-Difference and Resemblance}

The relation to the other opens up a space that is not necessarily simply theological but can also function as the source of theological discourse. As Derrida remarks regarding Levinas's entire enterprise, "this return to experience and 'to the things themselves,' as a relation to the infinte(ly) other is not theological, even if it alone has the power afterward to found theological discourse" (ED 159/107-8). If God, the most proper name, were not thought of as a substance, an ineffable Being, a presence, a final anchor term, but rather was the name of an "endless desertification of language,"32 if the name of God were the result of an always possible "movement of the effacement of the trace in presence" (ED 160/108), then the 'theological' would be, as Derrida writes in Of Grammatolgy, "a determinant moment in the total movement of the trace,"33 an "effect of the trace" (ED 160/108). God would be, a "nominal effect" within "the chains of substitutions of names," a name substituting yet another totally other for the wholly other. ${ }^{34}$ This possibility of infinite substitution, the infinite substitution of the infinite, allows "God" to stand for the name, one of the substitutable names, of the unsubstitutable. Such an account would, of course, break with all the monotheistic doctrines of the oneness, uniqueness, and unsubstitutability of God. It is said that the absolute uniqueness of Yahweh does not lend itself to analogy, yet in this uniqueness and irreplaceability analogy begins. ${ }^{35}$ Thus when we say that the relation to the other resembles the relation of Moses to God, we mean that not only is there a formal resemblance between the two relations but that "the other" shares a number of characteristics with 


\section{KAS SAGHAFI}

what we call "God." There is a structural analogy between the two relations.

In traditional analogy either (a) two quantities of the same kind are in a direct relation where the value of one determines the value of the other (proportio), or (b) there is a similarity or resemblance of relations, similitude proportionum, between the terms (proportionalitas). ${ }^{36}$ The etymology of "analogy" [ana-logia]-the repetition (ana) of a logos (of a relation or a ratio)-points to the possibility of a convertibility or conversion and a reversibility, since ana means reversal as well as repetition (as return, reversion, and inversion). ${ }^{37}$ Thus analogy implies a double movement: the repetition of an initial relation and the reversibility or reversal of a relation. ${ }^{38}$

For Derrida, analogy is traditionally anchored by the proper name or noun [idion onoma], where the proper name functions as "the nonmetaphorical prime mover of metaphor," as a first term or causality. ${ }^{39}$ Traditional analogy-what Derrida has elsewhere called "anaonto-logy," which is dominated by the necessity of "the appearance as such of the as such, of the as"-is governed by the proper name of the logos outside and beyond language. The origin of analogy has always been logos-reason and word-what "regulates all analogy and which itself is not analogical." ${ }^{\prime 40}$ The analogical chain proceeds from and always comes back to an origin, to truth, whose value governs the entire chain. This return is guided by the function of resemblance (bomoiosis): the proper and the metaphor reflect and refer to each other, where the proper noun has a single sense and means only one thing. The logical and metaphysical anteriority of that which is resembled is never contested. Traditional analogy also assumes that the identity of the terms in the analogical relation and their relationships are evident, known, and stable. In other words, all the terms are either present or can come to presence.

The relation or analogy between two relations is itself dominated and named by one of the terms within the relation of relations, for example, in our case, God. The name of the relation is the same as that of one of its terms and all the terms are comprehended in the structure of this one term. "This comprehension," according to Derrida, "is an act of domination and decision." "Thus the relation itself is comprehended and decided in favor of one of its terms. "God," then would dominate the other terms of the analogy, swallowing them up, incorporating them.

For Derrida, in the analogy of the relation to the other to that of 
the relation of Moses to God--analogy displaced, analogy otherwise, an almost-unheard of "analogy," analogy and heterology-what the terms of the analogy name, for example "God" or "the other," are not the proper names referring to a unique thing. The analogy does not refer back to a fixed term or an undivided origin. The relation to both, the other and God, is an indirect, reticent rapport to a certain obscurity and remoteness. What both relations have in common is a structural similarity: both are asymmetrical relations to that which is infinitely distant, to what cannot be seen or immediately presented. The description of one relation-for example, the characteristics of the relation to the other-can then shine a light, albeit a nocturnal glow, on the other relation.

Following the same logic to its limit, we could say that the relation to the other and the relation of Moses to God are at once analogous, they share a certain functional analogy (hence this relation could be inscribed in an open series which would contain many other analogous relations) and also remain entirely singular, irreducible to one another, offering no guarantee of analogy. Each relation, utterly unique, singular and irreplaceable, is part of a specific semantic or tropological system, and can be substituted by another. Each relation is a part of a series, but is also able to comprehend the whole and stand for all the others. If there is an analogy between the relation of Moses and God, analogy is here understood in a new sense, combining "the economy of analogy - the same only differed, relayed, deferred [reporte] — and the rupture of all analogy, absolute heterology." ${ }^{\text {"42 }}$ It is an interrupted analogy, which once interrupted, is again resumed as an analogy between two absolute incommensurable heterogeneities.

\section{Paradigm and Series}

Thus, the relation between Moses and God can be taken as the paradigm, paradeigma, example, for all relations to the other. In both cases a demand is made for the other to show itself ("montre-toi"), and each time this demand cannot be fulfilled. What is asked to show itself cannot show itself in person; it erases itself in 'presenting' itself, disappearing in its appeatance. Hence there can be no relation to the other or to God as such, there can only be a relation to the other as other.

The relation of Moses to God is exemplary and can function as the paradigm for all relations to the other, but this paradigm has no absolute privilege with respect to other relations in the open-ended 


\section{KAS SAGHAFI}

series of relations in which it is inscribed and that it makes possible. The paradigm here is neither the producer nor the generator from which a copy emerges. It is not at the origin, arché, or the model already there, in nature, from which other relations originate. This series without commencement or end, without origin or hierarchy, is composed of a chain of relations, an open series of relations, each unique and irreplaceable. The relation of Moses to God is a part of this series, which we may just as well call, without paradigm, but a part that can always comprehend the whole. If the series of relations are analogous it is in their disjunction-they are interlaced but interrupted at intervals.

Read in this manner, even if the relation of Moses to God is to be considered as the paradigm of all relations to the other, the relationship to the other need not necessarily be a "religious" relation understood onto-theologically. In "Violence and Metaphysics" Derrida found it objectionable to call the relation which opens ethics, this bond or tie, religion. At that time, Derrida demonstrated that Levinas was unable to escape the theological ambit of his thought, that he was unable to keep the philosophical texts and the confessional, theological writings apart. ${ }^{43}$ Since those early pronouncements Derrida's own work has undertaken a serious engagement with religion, and he would be more tempted to accept the term religion, as long as this relation could be understood as the inescapable relationship to a non-thematizable $\mathrm{X}$, a relation without relation to the totally other rather than an organized, positive, revealed religion. ${ }^{44}$ Yet he would still maintain that Levinas's insistence on keeping the two realms separate leads to a metaphysical, onto-theological thought.

For Derrida, the impossibility of rigorously separating the two relations - the relation of Moses to God and the relation to the otherfrom one another is precisely the very condition of any relation or address to the other. What cannot be denied is the primal importance of the relation to the other, an undeniable tie or "bond" that precedes all determined community, all organized religion, every onto-anthropotheological horizon. This bond would be what would link singularities to each other before any social or political determination. Thus what both sides of analogy between the two relations point to is the law of the relation to the other - a tie prior to all anthropo-theology, a relation anterior to the bond between men, and prior to what links man to God. To have a relation to the other as other is not to simply have respect for the other as buman subject, which Levinas's notion of Autrui would seem to insist on, it is to be in relation with that which comes, beyond being, 
whose identity is always yet to be determined. Perhaps the resemblance of the other to God as the movement of the trace is that very "space" in which the undecidable coming of the other occurs. It is in this way that the coming of the other "can no longer be confused with the God or the Man of onto-theology or with any of the figures of the configuration (the subject, consciousness, the unconscious, the self, man or woman, and so on)." 45

\section{Villanova University}

\section{Notes}

Parts of this article were written thanks to a Competitive Research Grant for summer research in Paris, awarded by the Committee for Support of Faculty Scholarship at Grinnell College. I would also like to express my gratitude to the Andrew W. Mellon Foundation and to Alan Schrift, the Director of the Center for the Humanities at Grinnell College, for their generous support.

${ }^{1}$ Hachem Foda, "En compagnie," Idiomes, nationalités, déconstruction:

Rencontre de Rabat avec Jacques Derrida, special issue of Cabiers INTERSIGNES 13 (Casablanca: Editions Toubkal, 1998), 20. All further references, abbreviated as IND, will be cited in the body of the text. Foda is referring to the French translation of Abu Bakr ibn Abi Ishaq Muhammad ibn Ibrahim ibn Ya'qub al-Bukhari al-Kalâbâdhîs Ta'arruf li-madhab abl al-tasanwuf, Traité du Soufisme, trans. Roger Deladrière (Paris: Sindbad, 1981); translated into English as The Doctrine of Sufis, trans. A. J. Arberry (Cambridge: Cambridge University Press, 1977).

${ }^{2}$ This is my translation of Foda's citation, "Montre-Toi à moi, que je Te regarde," from the Traité du Soufisme.

${ }^{3} \mathrm{I}$ am here translating Foda's rendering in French, ${ }^{\circ} \mathrm{Tu}$ ne Me verras point," of a citation from the Qur'an VII, 143. The King James Version of the Bible reads: "And he said, I beseech thee, show me thy glory." In his response God states: "for there no man shall see me" (Exodus 33:18-20).

${ }^{4}$ Jacques Derrida, "Fidélité à plus d'un," in Idiomes, nationalités, déconstruction: Rencontre de Rabat avec Jacques Derrida (Casablanca: Editions Toublal, 1998), 226, my italics.

${ }^{5}$ See, for example, Levinas's following remarks in an interview with Richard Kearney regarding the difference between his two forms of writing: "I always make a clear distinction in what I write, between philosophical and confessional texts....I would never, for example, introduce a talmudic or biblical verse into one of my philosophical texts to try to prove or justify a phenomenological argument." "Dialogue with Emmanuel Levinas" in Face to 
Face with Levinas, ed. Richard Cohen (Albany: State University of New York Press, 1986), 18.

'Jacques Derrida, "Violence et métaphysique," in L'Ecriture et la difference (Paris: Seuil, 1967); translated by Alan Bass as "Violence and Metaphysics" in Writing and Difference (Chicago: University of Chicago Press, 1978). Cited throughout as ED in the body of the text, with the page references first to the French, then to the English. I have silently modified the translation where necessary. This article was first published in two parts in Revue de métapbysique et de morale 69:3 (1964): 332-345 and 69:4 (1964): 425-473.

7 Autrui is often rendered in English as "others" (e.g., Harper CollinsRobert French Dictionary); however, in translations of Levinas the term is customarily translated in the uppercase as "the Other" to indicate that Levinas's concern is always with a human other. For Levinas, Autrui is a concrete reference to the other person, to the empirically human, whereas the use of Autre tends to stress the formal sense of alterity, even though he is not consistent about this throughout his writings. The French Robert dictionary provides the following entry for autrui: "(pronom)_altrui 1080, cas régime de autre; un autre, les autre hommes." The following etymology can be found in the Littré: "Provençal altrui, autrui; ital. altrui; de alter-buic, cet autre, à un cas régime: voilà pourquoi autrui est toujours au régime, et pourquoi autrui est moins général que les autres." Perhaps, like the translators of Being and Time who chose not to translate Dasein, philosophical English should adopt Autrui as a more acceptable term than "the Other." This practice is followed by Susan Hanson in the translation of Blanchot's The Infinite Conversation. Since one of the purposes of this paper is to disentangle the different conceptions of the term "other" in the works of Levinas and Derrida, I have retained the French terms throughout in my essay. Also, I have maintained Derrida's use of the lower case l'autre, the other, in order to emphasize how he utilizes this term.

${ }^{8}$ The complex relation between Derrida and Levinas, involving a number of texts over the course of decades, would naturally require a careful analysis that cannot be undertaken here. It needs to be remembered (1) that "Violence and Metaphysics" mainly treats Levinas's early writings (Derrida notes that his essay was already written before the publication of "The Trace of the Other" in 1963), and (2) that certain terms and motifs have shuttled back and forth between the two authors and a nuanced reading of the relation between the two thinkers would have to take into account this mutual rereading. My concern in this essay is not whether Derrida's interpretation of Levinas is "accurate," nor is it to provide Levinasian "responses" to any of Derrida's "objections."

${ }^{9}$ Since the aim of this essay is to attend to Derrida's reading of Husserl, we would have to leave aside an examination of Husserl's own texts. It is worth noting, however, that throughout his writings, from the Husserliana 


\section{'AN ALMOST UNHEARD-OF ANALOGY'}

volumes XIII-XV Zur Pbänomenologie der Intersubjektiviät (1905-35) to Formal and Transcendental Logic and the Cartesian Meditations, Husserl maintained that there can be no presentation (Gegenwärtigung) of the other's lived experiences. I can never have unmediated access to the other. Since the other cannot be given in flesh and blood, it never offers itself originaliter [originär], it can only be analogically appresented. In the Cartesian Meditations Husserl insists that the experience of the other, Fremderfabrung, is not an inference from analogy or reasoning by analogy $(\$ 50)$. Apperception is not a thinking act or a projection, rather the relation to the alter ego or the alien (Husserl uses the adjective das fremde) is a transfer, an analogizing transposition. Husserl uses the terms analogization [Analogisierung] and analogon frequently to signify a process rather than a state. See, for example, Hua XIII, 265 and CM $\$ 44$, Hua I, 125: "The other [der Andere] is my analogon."

${ }^{10}$ For another reference to analogical appresentation, see Voice and Phenomenon where Derrida writes: "outside the transcendental monadic sphere of what is my own (mir eigenes), the ownness [la propriéte] of my own (Eigenbeit), my own self-presence, I only have relations of analogical appresentation, of mediate and potential intentionality, with the other's ownness [le propre d'autrui], with the self-presence of the other; its primordial presentation is closed to me [le présentation originaire m'est interdite." La voix et le phénomène (Paris: Presses Universitaires de France, 1967), 42; translated by David Allison as Speech and Phenomena (Evanston: Northwestern University Press, 1973), 39.

${ }^{11}$ See Jacques Derrida, "Il faut bien manger," Points de suspension: entretiens, ed. Elisabeth Weber (Paris: Galilée, 1992), 278; translated by Peter Connor and Avital Ronell as "Eating Well," Points .... Interviens, 1974-1994, trans. Peggy Kamuf et al. (Stanford: Stanford University Press, 1995), 263-4.

${ }^{12}$ Jacques Derrida, Le toucher, Jean Luc Nancy (Paris: Galilée), p. 218. All further references will be cited as LT in the body of the text.

${ }^{13}$ Derrida goes on to add that this economic relationship is also at the same time a relation of violence and nonviolence (188/128-9). The question of violence in the works of Levinas and Derrida has been the subject of much controversy, which cannot be broached here.

${ }^{14}$ We know from Plato's Sopbist that to be other is to be other than something else: "other is always said relative to other [pros heteron]." Plato, Sophist, Loeb Classical Library, vol. VII, trans. Harold North Fowler (Cambridge, Mass: Harvard University Press, 1996 [1 ${ }^{\text {st }}$ ed. 1921]), 255d. Stanley Rosen, in Plato's Sophist: The Drama of Original and Image (New Haven: Yale University Press, 1983), 271, renders this passage as: "whatever is other is necessarily this specific nature with respect to another" (255d6-7). Also see Parmenides $139 \mathrm{c}$ and $164 \mathrm{c}$. Derrida notes that even though the other is always said pros heteron, this "does not prevent it from being an eidos (or a genre [genus] in a nonconceptual sense) that is, from being the same as itself," as long as we understand this sameness to involve alterity (186/127). 


\section{KAS SAGHAFI}

The notion of the other in Plato, whether allo or beteron, is especially difficult to comprehend, particularly in the later dialogues. See Stella Sandford's excellent "Plato and Levinas: The Same and The Other," Journal of the British Society for Phenomenology 30:2 (May 1999): 131-150. Sandford cites Jean Wahl, who in 1926 wrote that the other is "unable to be grasped [insaisissable] by pure conceptual thought," and Paul Ricoeur, who calls the other "the most ungraspable [insaisissable] of the categories" (141).

forthcoming.

${ }^{15}$ See my essay " "Ca me regarde': Regarding Responsibility in Derrida,"

${ }^{16}$ For two penetrating analyses of Derrida's reading of the notion of the other in Husserl in "Violence and Metaphysics," see Robert Bernasconi, "The Alterity of the Stranger and the Experience of the Alien," in The Face of the Other and the Trace of God: Essays on the Pbilosophy of Emmanuel Levinas, ed. Jeffrey Bloechl (New York: Fordham University Press, 2000) and Leonard Lawlor, Derrida and Husserl: The Basic Problem of Phenomenology (Bloomington: Indiana University Press, 2002).

${ }^{17}$ When discussing Levinas's work in "Violence and Metaphysics," following Levinas's own practice in Totality and Infinity, Derrida uses autrui and l'autre synonymously. It should be noted that, even when providing an account of the characteristics of the other in Levinas, Derrida consistently uses l'autre in the lower case. Autrui is a term that does not belong to Derrida's terminology. 18 "The absolutely other is Autrui [L'absolument Autre, c'est Autrui]." Emmanuel Lévinas, Totalité et infini: Essai sur l'extériorité (The Hague: Martinus Nijhoff, 1961), 28. All page references in this essay are to the Livre de poche edition; translated by Alphonso Lingis as Totality and Infinity: An Essay on Exteriority (Pittsburgh: Duquesne University Press, 1969), 39. Hereafter cited throughout in the body of the text as TI, with the page references first to the French, then to the English.

${ }^{19}$ One cannot but hear in the words plus tôt, "even earlier," echoes of another word, plutôt, "rather." Rather, Derrida seems to be asking, what does autre mean before its Greek and Judeo-Christian determinations?

${ }^{20}$ 'The "thou" is an obvious reference to Buber's work which is founded on an ontology and a theology of the "l'entre-deux."

${ }^{21}$ It is clearly not possible to fully substantiate this claim in the space of one essay.

${ }^{22}$ Jacques Derrida, Adieu à Emmanuel Lévinas (Paris: Galilée, 1997), 100; translated by Pascale-Anne Brault and Michael Naas as Adieu: To Emmanuel Levinas (Stanford: Stanford University Press, 1999), 54.

${ }^{23}$ Jacques Derrida and Pierre-Jean Labarièrre, Altérités (Paris: Osiris, 1986), 81-2. My account of the relation to the other in this section borrows heavily from this text.

${ }^{24}$ For a partial list of Derrida's references to analogy, see the discussion of "the principle of analogy" in Archeology of the Frivolous, Voice and 
Phenomenon, "Ousia and Gramme" and "White Mythology" (where metaphor is called "the manifestation of analogy") in Margins of Pbilosopby, "Plato's Pharmacy" in Dissemination, "Parergon" in The Trutb in Painting (where Derrida notes the connection between anthropo-theologism and analogism), "Economimesis," " To Speculate-on "Freud"' in The Post Card, On the Name, Signsponge, "Shibboleth: For Paul Celan," and The Gift of Death.

${ }^{25}$ Analogy is also italicized on ED 148, not reflected in the English translation on $\mathrm{p} .100$.

${ }^{26}$ This is a quotation from TI $326 / 293$.

${ }^{27}$ We can find in the writings of Saint Bonaventure references to a resemblance (similitudo) between creatures and God. In the Commentary on the Senses he wrote that the likeness of creature to God is a relation of proportionalitas. The relationship of creature to God is that of the exemplatum to the exemplar, making every creature a vestigium Dei. For Aquinas, the foundation of all analogy is also the likeness of creatures to God. Analogical predication is founded on resemblance. In De Veritate Aquinas distinguishes the resemblance of proportion (convenientia proportionis) from the resemblance of proportionality (convenientia proportionalitas). In the Summa Theologica I Aquinas writes of an analogy of proportion, analogia secundum convenientiam proportionis, and proportionality, analogia secundum convenientiam proportionalitas. In Aquinas, analogy plays an important role as a supplement to human logos in understanding God. See George Peter Klubertanz, St. Thomas Aquinas on Analogy: A Textual Analysis and Systematic Synthesis (Loyola University Press, 1960).

${ }^{28}$ In an interview, Levinas clarifies the relation between God and autrui: "I cannot describe the relation to God without speaking of my concern for autrui [ce qui m'engage a l'egard d' autrui]." Adding that in Matthew, 25 the relation to God is presented as "a relation to another person [l'autre homme]," Levinas says: "In autrui there is the real presence of God." See "Philosophie, Justice et Amour" in Entre nous: Essais sur le penser-a-l'autre (Paris: Grasset, 1991), 120-1; translated by Michael B. Smith and Barbara Harshav as "Philosophy, Justice and Love" in Entre nous: Thinking-of-The-Other (New York: Columbia University Press, 1998), 109-110, trans. modified.

${ }^{29} \mathrm{I}$ am here citing the translation used by Alan Bass in Writing and Difference which differs slightly from the one with which my essay began.

${ }^{30}$ In the context of a discussion of the role of art in "Reality and Its Shadow," Levinas writes of a resemblance without model. Historically resemblance has been understood as a relation between the thing and its image, a comparison between an image and the original. In this extremely tich earty essay, Levinas thinks of resemblance as the very movement that engenders the image. The thing, he writes, resembles itself. See "La réalité et son ombre," Les Temps modernes 38 (1948): 771-789; translated by Alphonso Lingis as "Reality and Its Shadow," in The Levinas Reader, ed. Seán Hand (Cambridge, Mass.: Blackwell, 1989). 


\section{KAS SAGHAFI}

${ }^{31}$ The main Scholastic philosophers (late fifteenth through sixteenthcenturies) associated with the question of analogy were, of course, Thomas de Vio (Cajetan), Peter de Fonseca, and Francis Suárez. In Disputationes metapbysicae Suárez wrote: "Every creature is being in virtue of a relation to God, inasmuch as it participates in or in some way imitates the being (esse) of God, and as having being, it depends essentially on God."

32 Jacques Derrida, Sauf le nom (Paris: Galilée, 1993), 56; translated by John P. Leavey, Jr. as "Sauf le nom" in On the Name, ed. Thomas Dutoit (Stanford: Stanford University Press, 1995), 55-6.

${ }^{33}$ Jacques Derrida, De la grammatologie (Paris: Minuit, 1967), 47; translated by Gayatri Chakravorty Spivak as Of Grammatology (Baltimore:Johns Hopkins University, 1974), 69.

${ }^{34}$ Jacques Derrida, "La Différance," Marges de la pbilosopbie (Paris: Minuit, 1972), 28; translated by Alan Bass as "Différance," Margins of Pbilosopby (Chicago: University of Chicago Press, 1982), 26-7.

${ }^{35}$ Derrida returns to the question of analogy and the Name of God in Levinas in "En ce moment même dans cet ouvrage me voici," Psyché. Inventions de l'autre (Paris: Galilée, 1987-98); translated by Ruben Berezdivin as "At This Very Moment in This Work Here I Am" in Re-Reading Levinas, eds. Robert Bernasconi and Simon Critchley (Bloomington: Indiana University Press, 1991). Quoting Levinas's words in "The Name of God According to a Few Talmudic Texts" where he emphasizes that God refuses all analogy with beings, Derrida adds that once interrupted, this analogy is again resumed. Just as there is a resemblance between the face of God and the face of man, Derrida writes, there is also an analogy between all proper names and the names of God, which are, in their turn, analogous among themselves.

${ }^{36}$ The terms proportio and proportionalitas are from the Latin translation of Euclid's The Thirteen Books of the Elements, vol. II. trans. Thomas L. Heath (New York: Dover, 1956) book 5, def. 3 and 5. The Latin word proportio translates the Greek analogia, a translation that already betrays a Platonic conceptualization of analogy.

${ }^{37}$ See Eliane Escoubas, Imago Mundi: Topologie de l'art (Paris: Galilée, 1986), 113. Ana has the same sense as the Latin re or retro. It can also mean "upward," and in certain circumstances "according to," "in mutual accord," "reciprocally."

38 The origins of analogy are somewhat obscure. A general theory of analogy was first developed by Eudoxus (?406-?355 BC) and then codified by Euclid. Whether credited to the Pythagoreans or their predecessors, the initial use of analogy was mathematical, where it signified the equality of two proportions. For the use of analogy in Plato, see Republic Bk VII 508c (analogon "to stand in a proportion with itself"); 534a ("the proportion [analogia] between the things"), 510a-b, 511e, 530d, 534a, 576c; Gorgias 465b-c, Phaedo 111a-b; and Timaeus 29c, 31 c, 32a-c, 69b. Aristotelian analogy also emphasizes the 
relation of "a proportion or equality of two relations" e.g., Nichomachean Ethics V, 6, 1131a30, Metapbysics 1003a33, 1017a, Rhetoric III, 10, 1411a1, 1411b5; III, 11, 1412a; Poetics, Topics 108a7-8, V, 8, 138b24, Politics 1296b. Derrida has repeatedly linked the problem of analogy and metaphor, noting that, for Aristotle, analogy is metaphor par excellence as it is based on an equality of relations (Rbetoric, Poetics).

It is well known that Franz Brentano's 1862 Von der mannigachen Bedeutung des Seienden nach Aristoteles (Hildesheim: G. Olms, 1960); edited and translated by Rolf George as On the Several Senses of Being in Aristotle (Berkeley: University of California Press, 1975) was influential on Heidegger (see "Letter to Richardson"). Brentano situated his work within the tradition of scholastic philosophy which attributed to Aristotle the determining of the manifold meanings of being in terms of analogy. However, many commentators of Aristotle have pointed out that for the Stagirite, it is more accurate to say that Being is said pros ben and not analogically (e.g., Metapbysics 1003a33). It is the Late Scholastics, and not Thomas Aquinas, who equate the Aristotelian pros ben legomenon with the analogy of attribution. Jean-François Courtine's recent Les catégories de lêtre. Etudes de pbilosophie ancienne et mediévale (Paris: Presses Universitaires de France, 2003) argues quite convincingly that the doctrine of analogy of being, analogia entis, appears much later in the commentators of Aquinas such as Capréolus (Jean Cabrol), Cajetan, and Suárez.

In Being and Time Heidegger poses the question: What constitutes the unity of the universal concept of being? Quoting Aristotle in the opening pages, Heidegger credits him with elevating this problem to a fundamental level. Being is not a genus, Heidegger notes, and the universality of Being transcends any universality of genus. In medieval theology being is designated as a 'transcendens.' According to Heidegger, Aristotle himself knew the unity of this transcendental 'universal' as a unity of analogy, but the Schoolmen who inherited the doctrine of the unity of analogy failed to explain how the unity of being is possible. Not only is the doctrine of the analogy of being not a solution to the Seinsfrage, Heidegger points out in a lecture course, Aristoteles, Metapbysik E 1-3, Von Wesen und Wirklichleeit der Kraft, GA 33, ed. Heinrich Hüni (Frankfort: Klostermann, 1981), 46; translated by Walter Brogan and Peter Warnek as Aristotle's Metapbysics Ė 1-3: On the Essence and Actuality of Force (Bloomington: Indiana University Press, 1995), 38; but it is the index of "the most stringent aporia," an "impasse [Ausweglosigkeit]." According to Heidegger it is impossible to illuminate the primary meaning of being until the question of time is broached.

In Kant, analogy is a "perfect resemblance or similarity of two relations between two quite dissimilar things [eine unvollkommene Äbnlichkeit zweier Verbältnisse zwischen gañ unäbnlichen Dingen bedeutet." Prolegomena zu einer jeden kï̈ftigen Metapbysik, die als Wissenschaft wird auftreten können (Hamburg: Felix Meiner Verlag, 1957), $\ 58,124$, Ak. 357-8; translated by James W. 


\section{KAS SAGHAFI}

Ellington as Prolegomena to any Future Metapbysics, Paul Carus trans. revised (Indianapolis: Hackett, 1977), 98. Analogy is then a matter of resemblance [Äbnlicbkeit] and relations [Verbältnisse]. Operating everywhere in the Critique of Judgment, analogy attempts to bridge the abyss between the two absolutely heterogeneous worlds of Nature and the Ethical. As Derrida writes in The Truth in Painting, "the recourse to analogy, the concept and the effect of analogy," in Kant "are or make the bridge itself" (43/36). See, for example, Critique of Judgment Ak 464. Derrida also underscores "the connection between anthropotheologism and analogism" in the Third Critique: "the principle of analogy is here indeed inseparable from an anthropocentric principle. The human center also stands in the middle [au milieu], between nature (animate or inanimate) and God" (133-4/117). For a guide to the question of analogy in Kant, see François Marty, La naissance de la métapbysique chez Kant. Une etude sur la notion kantienne d'analogie (Paris: Beauchesne, 1980).

${ }^{39}$ Jacques Derrida, "La mythologie blanche," Marges de la philosophie (Paris: Minuit, 1972), 290; translated by Alan Bass as "White Mythology," Margins of Pbilosopby (Chicago: University of Chicago Press, 1982), 243.

${ }^{40}$ Jacques Derrida, "Economimesis" in Mimesis des articulations (Paris: Aubier-Flammarion, 1975), 85; translated by Richard Klein as "Economimesis" Diacritics 11, 2 (1981): 19.

${ }^{41}$ Jacques Derrida, "La pharmacie de Platon," La dissémination (Paris: Seuil, 1972), 133; translated by Barbara Johnson as "Plato's Pharmacy," Dissemination (Chicago: University of Chicago Press, 1981), 117.

${ }^{42}$ Jacques Derrida, "Comme si c'était possible," Revue internationale de pbilosopbie 205, 3 (1998): 497-529, p. 524.

${ }^{43}$ Referring to Difficult Freedom Derrida states that the ethical relation is a religious relation (142/96). The source of concern for Derrida is that Levinasian ethics inevitably leads to "religion," "not $a$ religion, but the religion, the religiosity of the religious" (142/96). Levinas defines religion in Totality and Infinity in the following ways: "We propose to call religion the bond [le lien] that is established between the same and the other without constituting a totality" (TI 30/40) and "For the relation between the being here below and the transcendent being that results in no community of concept or totalitya relation without relation-we reserve the term religion" (TI 78-9/80). This term is, of course, revisited by Derrida in "Foi et savoir: Les deux sources de la 'religion' aux limites de la simple raison." In La Religion. Eds. Jacques Derrida and Gianni Vattimo (Paris: Seuil, 1996); translated by Samuel Weber as "Faith and Knowledge: The Two sources of 'Religion' within the Limits of Mere Reason," in Religion (Stanford: Stanford University Press, 1998).

${ }^{44}$ Both Hent de Vries, from whose work I have benefited greatly, and John Caputo have written extensively on Derrida's writings on religion. See Hent de Vries, Philosopby and the Turn to Religion (Baltimore: Johns Hopkins University Press, 1999) and Religion and Violence: Philosopbical Perspectives from 


\section{'AN ALMOST UNHEARD-OF ANALOGY'}

Kant to Derrida (Baltimore: Johns Hopkins University Press, 2002) and John Caputo, The Prayers and Tears of Jacques Derrida: Religion without Religion (Bloomington: Indiana University Press, 1997).

${ }^{45}$ Jacques Derrida, "Psyché: Invention de l'autre," in Psyché. Inventions

de l'autre (Paris: Galilee, 1987-98), 61, translated by Catherine Porter as "Psyche: Inventions of the Other," in Reading De Man Reading, eds. Lindsay Waters and Wlad Godzich (Minneapolis: University of Minnesota Press, 1989), 61. 